\title{
Risk of relapse among non-lepromatous patients released from treatment after dapsone monotherapy
}

\author{
T D PANDIAN, * JAYAPRAKASH MULIYIL $\dagger, \S \&$ \\ C VELLUT $\ddagger$ \\ *DANLEP, 10 Gandhi Road, Salem 636 007, India; †Community \\ Health Department, Christian Medical College, Bagayam, Vellore \\ 632 002, India; and $\ddagger$ Damien Foundation, AL-189, 1st Street, \\ 12th Main Road, Anna Nagar (West), Madras 600 040, India
}

\begin{abstract}
Accepted for publication 1 February 1991
Summary Information on 14,625 non-lepromatous patients released from treatment after dapsone monotherapy and followed up to a maximum of 15 years at the ILEP project, Dharmapuri, India, was analysed to study the pattern of relapses. The overall relapse rate was $5 / 1000$ person years. Males had a higher relapse rate than females. The risk of relapse increased with age, number of lesions and duration of treatment. The risk for relapse remained constant over several years after release from treatment. Even though the absolute risk for relapse after MDT may be different, the pattern of relapses and the factors affecting it may be similar to what has been shown in this study.
\end{abstract}

\section{Introduction}

With the introduction of multidrug therapy the prevalence of leprosy cases requiring treatment has reduced in many endemic districts of India. Paucibacillary cases are being maintained under surveillance for 2 years after treatment, for the early diagnosis of treatment failures, relapses and reactions. There are also a large number of nonlepromatous patients who have been released from treatment after dapsone monotherapy. At present there is very little information on their long term risk for relapse. Further, identification of factors which modify the risk for relapse following dapsone monotherapy, may facilitate the planning of follow-up procedures for patients released after MDT. With this in view a historical cohort study was carried out at the ILEP Leprosy Control project at Dharmapuri, Tamil Nadu, India, to measure the relapse rates among non-lepromatous patients treated with dapsone monotherapy and factors affecting the risk for relapse. 


\section{Background information}

The ILEP programme at Dharmapuri was started in 1968 by the Damien Foundation. It was covering a population of 1 million when the project was handed over to the Government of Tamil Nadu in 1985. Throughout this period the unit had maintained a high level of efficiency in leprosy control work and documentation. The population covered by this unit was essentially rural. The control work was based on the guidelines suggested by the National Leprosy Control Programme. Cases were classified into 'N', 'N?L' and ' $L$ ', according to the practice prevalent at that time. ' $N$ ' included TT and early BT cases and ' $N$ ? L' included the more advanced BT and BB. BL and LL cases were put under ' $L$ '. Apart from this, bacteriologically negative cases with macular lesions were classified as 'I'. This probably included a wide range of cases. Polyneuritic cases were classified as ' $\mathrm{P}$ '.

Until 1971 dapsone was administered in gradually increasing doses up to a maximum of $300 \mathrm{mg}$ per week for adults; children received half that dose. From 1972 this practice of gradually increasing the dose was given up and the maximum dose was increased to $400 \mathrm{mg}$ per week. From 1975 the dose of dapsone was further increased so that the adults received a maximum of $700 \mathrm{mg}$ per week. Patients were declared inactive when the lesions had disappeared, or when a previously raised lesion had become macular or wrinkled in the absence of any evidence of neuritis.

After inactivity, non-lepromatous patients were maintained on the same dose of dapsone for a period of $1 \frac{1}{2}$ to 5 years, wherever possible, before being declared as released from treatment (RFT). These patients were indefinitely followed up during the annual 'known case verification'. The treatment cards contained all the relevant information including details regarding relapses. The criteria for relapse were the following:

(a) Evidence of recurrence of activity in the old lesion;

(b) Appearance of a new lesion;

(c) Evidence of new nerve involvement.

All relapses were seen and confirmed by a medical officer.

\section{Methodology}

All non-lepromatous patients released from treatment from 1968 to 1985 were included in the study. Those who were known to have left the area or died were excluded. The individual treatment cards were reviewed carefully and information regarding personal characteristics, nature and extent of the disease, number of weeks of treatment, date of RFT and date of relapse (if relapsed) were extracted. The duration of treatment was calculated from the information on the number of weeks for which treatment was administered to the patients. The information was fed into a computer and analysed using SPSS PC.

Relapse rates were calculated as

$$
=\frac{\text { No. of relapses } \times 1000}{\text { No. of person years of follow-up }} .
$$


Cases were assumed to have been released from treatment uniformly throughout the year, thus contributing on average half a person year of observation each, during the calender year of RFT. Risk of relapse and cumulative risk for relapse were calculated using the actuarial method. Since cases who had died or left the area were excluded from the study, all the withdrawals were due to censoring caused by the study. Hazard ratios for relapses were calculated based on Cox's proportional hazards model using EGRET.

\section{Results}

Of the 14,889 records examined 264 had to be excluded due to incompleteness of information. The remaining 14,625 patients had been followed up for a maximum period of 15 years (mean $=5 \cdot 2$ years; $\mathrm{SD}=3 \cdot 3$ years) after RFT. There were 387 relapses during $75,916 \cdot 5$ person years of follow-up giving an overall relapse rate of $5 \cdot 1 / 1000$ person years.

As shown in Table 1 the relapse rates were lowest for the ' $N$ ' type (4.6/1000 per year). 'N?L' and polyneuritic cases had similar relapse rates. Indeterminate cases had the highest relapse rates $(24 / 1000)$. The differences in relapse rates between ' $N$ ' and other types were statistically significant $(P<0.05)$. Relapse rate among males was $80 \%$ higher than that among females (Table 2) $(P<0.001)$. Relapse rates appeared to increase with age at diagnosis until 30 years (Table 3). After that the relapse rate showed a fall. A similar trend was noticed when relapse rates were analysed according to age at RFT (Table 4). Relapse rate tended to increase with duration of treatment (Table 5). When the relapse rates were examined according to the three different periods with different treatment schedules, no significant differences were noticed (Table 6).

Relapse rates increased with the number of patches at the time of diagnosis (Table 7).

Table 1. Relapse rates according to type of leprosy

\begin{tabular}{|c|c|c|c|c|}
\hline Type & $\begin{array}{l}\text { No. of } \\
\text { cases }\end{array}$ & $\begin{array}{l}\text { Person years } \\
\text { of follow-up }\end{array}$ & Relapse & $\begin{array}{c}\text { Rate } / 1000 \\
\text { PY }\end{array}$ \\
\hline $\mathrm{N}$ & 13,395 & $71,620 \cdot 5$ & 331 & $4 \cdot 62$ \\
\hline N?L & 727 & $1,509 \cdot 5$ & 20 & $13 \cdot 24$ \\
\hline Polyneuritic & 459 & $2,619 \cdot 5$ & 32 & $12 \cdot 21$ \\
\hline \multirow[t]{2}{*}{ I } & 44 & $167 \cdot 0$ & 4 & 23.95 \\
\hline & 14,625 & $75,916 \cdot 5$ & 387 & $5 \cdot 1$ \\
\hline
\end{tabular}

Table 2. Relapse rates by sex

\begin{tabular}{|c|c|c|c|c|c|}
\hline Sex & $\begin{array}{c}\text { No. of } \\
\text { patients }\end{array}$ & $\begin{array}{c}\text { Person } \\
\text { years }\end{array}$ & $\begin{array}{l}\text { No. of } \\
\text { relapses }\end{array}$ & $\begin{array}{l}\text { Rate/1000 } \\
\text { PY }\end{array}$ & $P$ \\
\hline \multirow{3}{*}{$\begin{array}{l}\text { Female } \\
\text { Male }\end{array}$} & 7,085 & $38,092 \cdot 5$ & 139 & $3 \cdot 65\}$ & \multirow{3}{*}{$<0.001$} \\
\hline & 7,540 & $37,824 \cdot 0$ & 248 & $6 \cdot 56\}$ & \\
\hline & 14,625 & $75,916 \cdot 5$ & 387 & $5 \cdot 1$ & \\
\hline
\end{tabular}


Table 3. Relapse rates by age at diagnosis

\begin{tabular}{lcccc}
\hline $\begin{array}{c}\text { Age } \\
\text { in years }\end{array}$ & $\begin{array}{c}\text { No. of } \\
\text { patients }\end{array}$ & $\begin{array}{c}\text { Person } \\
\text { years }\end{array}$ & $\begin{array}{c}\text { No. of } \\
\text { relapses }\end{array}$ & Rate/1000 \\
\hline $1-10$ & 2,564 & 15,616 & 40 & $2 \cdot 56$ \\
$11-20$ & 2,264 & 12,325 & 72 & $5 \cdot 84$ \\
$21-30$ & 2,285 & $11,553 \cdot 5$ & 86 & $7 \cdot 44$ \\
$31-40$ & 3,203 & $16,343 \cdot 5$ & 112 & $6 \cdot 85$ \\
$41 \&$ above & 4,309 & $20,078 \cdot 5$ & 77 & $3 \cdot 83$ \\
\cline { 2 - 5 } & 14,625 & $75,916 \cdot 5$ & 387 & $5 \cdot 1$ \\
\hline
\end{tabular}

Table 4. Relapse rates by age at RFT

\begin{tabular}{lrrrr}
\hline $\begin{array}{c}\text { Age at } \\
\text { RFT }\end{array}$ & $\begin{array}{c}\text { No. of } \\
\text { patients }\end{array}$ & $\begin{array}{c}\text { Person } \\
\text { years }\end{array}$ & $\begin{array}{c}\text { No. of } \\
\text { relapses }\end{array}$ & Rate/1000 \\
\hline $1-10$ & 480 & $3,751 \cdot 0$ & 7 & $1 \cdot 87$ \\
$11-20$ & 3,237 & $19,508 \cdot 5$ & 65 & $3 \cdot 33$ \\
$21-30$ & 1,758 & $8,551 \cdot 0$ & 62 & $7 \cdot 25$ \\
$31-40$ & 2,605 & $13,795 \cdot 5$ & 104 & $7 \cdot 54$ \\
$41 \&$ above & 6,545 & $30,310 \cdot 5$ & 149 & $4 \cdot 92$ \\
\cline { 2 - 5 } & 14,625 & $75,916 \cdot 5$ & 387 & \\
\hline
\end{tabular}

Table 5. Relapse rates by duration of treatment

\begin{tabular}{|c|c|c|c|c|c|}
\hline $\begin{array}{l}\text { Duration of treatment } \\
\text { in years }\end{array}$ & $\begin{array}{l}\text { No. of } \\
\text { patients }\end{array}$ & $\begin{array}{l}\text { Person } \\
\text { years }\end{array}$ & $\begin{array}{l}\text { No. of } \\
\text { relapses }\end{array}$ & Rate/1000 & $P$ \\
\hline \multirow{4}{*}{$\begin{array}{l}\text { Up to } 3 \\
4-5 \\
6 \text { \& above }\end{array}$} & 7,616 & $43,413 \cdot 0$ & 174 & $4.0\}$ & \multirow{4}{*}{$\begin{array}{l}<0.05 \\
<0.01\end{array}$} \\
\hline & 4,047 & $19,398 \cdot 5$ & 107 & $5 \cdot 5\}$ & \\
\hline & 2,962 & $13,105 \cdot 0$ & 106 & $8 \cdot 1\}$ & \\
\hline & 14,625 & $75,916 \cdot 5$ & 387 & & \\
\hline
\end{tabular}

Table 6. Relapse rates according to the period of registration

\begin{tabular}{|c|c|c|c|c|}
\hline $\begin{array}{l}\text { Period of } \\
\text { registration }\end{array}$ & $\begin{array}{c}\text { Person } \\
\text { years }\end{array}$ & $\begin{array}{l}\text { No. of } \\
\text { relapses }\end{array}$ & Relapse rate & $P$ \\
\hline 1968-1971 & $49,821 \cdot 5$ & 255 & $5 \cdot 1\}$ & \\
\hline $1972-1974$ & $14,691 \cdot 0$ & 82 & $5.6\}$ & $\begin{array}{l}\text { NS } \\
\text { NS }\end{array}$ \\
\hline \multirow[t]{2}{*}{$1975-1984$} & $11,404 \cdot 0$ & 50 & $4 \cdot 4\}$ & NS \\
\hline & $75,916 \cdot 5$ & & & \\
\hline
\end{tabular}


Table 7. Relapse rates by number of patches

\begin{tabular}{|c|c|c|c|c|}
\hline $\begin{array}{l}\text { No. of } \\
\text { patches }\end{array}$ & $\begin{array}{c}\text { No. of } \\
\text { patients }\end{array}$ & $\begin{array}{c}\text { Person } \\
\text { year }\end{array}$ & $\begin{array}{l}\text { No. of } \\
\text { relapses }\end{array}$ & Rate/1000* \\
\hline 1 & 6,797 & $38,062 \cdot 5$ & 127 & $3 \cdot 34$ \\
\hline $2-3$ & 3,872 & $21,026 \cdot 0$ & 96 & $4 \cdot 57$ \\
\hline $4-6$ & 1,513 & $7,089 \cdot 0$ & 52 & $7 \cdot 34$ \\
\hline $7-10$ & 736 & 3,094 & 28 & $9 \cdot 05$ \\
\hline \multirow[t]{2}{*}{$>10$} & 1,248 & 4,025 & 52 & 12.92 \\
\hline & $14,166 \dagger$ & $73,297 \cdot 0$ & 355 & \\
\hline
\end{tabular}

Graph 1 shows the cumulative risk of relapse according to the number of patches. For patients with more than 10 patches the probability of relapse by the 7 th year was $10 \%$.

The annual risk of relapse after RFT was stable at around 5/1000 during the first 7 years. There was a slight decrease in the relapse rate af ter 7 years (Table 8). This fall is to be expected since there were hardly any cases with more serious forms of disease who had been followed up for more than 7 years.

The effect of the number of patches, duration of treatment and age at diagnosis on the risk for relapse were examined by doing survival analysis using Cox's proportional hazards model for males and females separately (Appendix I \& II). The relative risk for relapse increased with the number of patches and duration of treatment as seen in the univariate analysis. However, the relative reduction in the risk for relapse after age 30 , seen in the univariate analysis, disappears when adjustments are made for the number of patches and duration of treatment. Thus the risk for relapse tends to increase with the age of the patient at detection. The pattern was similar when age at RFT was entered into the model instead of age at detection.

Table 8. Risk of relapse by year of follow-up

\begin{tabular}{cccccc}
\hline $\begin{array}{c}\text { Years } \\
\text { after RFT }\end{array}$ & $\begin{array}{c}\text { No. starting } \\
\text { the period }\end{array}$ & Relapse & $\begin{array}{c}\text { Withdrawals } \\
\text { during the year }\end{array}$ & Risk/1000 & $\begin{array}{c}\text { Cumulative probability } \\
\text { of relapse/1000 }\end{array}$ \\
\hline 1 & 14,625 & 64 & 1,385 & $4 \cdot 59$ & $4 \cdot 6$ \\
2 & 13,176 & 78 & 1,393 & $6 \cdot 25$ & $10 \cdot 8$ \\
3 & 11,705 & 66 & 1,476 & $6 \cdot 02$ & $16 \cdot 7$ \\
4 & 10,163 & 50 & 1,361 & $5 \cdot 27$ & $21 \cdot 9$ \\
5 & 8,752 & 40 & 1,891 & $5 \cdot 12$ & $26 \cdot 9$ \\
6 & 6,821 & 33 & 1,581 & $5 \cdot 47$ & $32 \cdot 3$ \\
7 & 5,207 & 27 & 1,085 & $5 \cdot 79$ & $40 \cdot 9$ \\
8 & 4,095 & 11 & 1,072 & $3 \cdot 091$ & $44 \cdot 1$ \\
9 & 3,012 & 9 & 563 & $3 \cdot 30$ & $45 \cdot 9$ \\
10 & 2,440 & 4 & 485 & $1 \cdot 82$ & $51 \cdot 0$ \\
11 & 1,951 & 3 & 1,085 & $2 \cdot 13$ & - \\
12 & 863 & 2 & 511 & $3 \cdot 30$ & - \\
13 & 350 & - & 285 & - & - \\
14 & 65 & - & 61 & - & \\
15 & 4 & - & - & - & \\
\hline
\end{tabular}




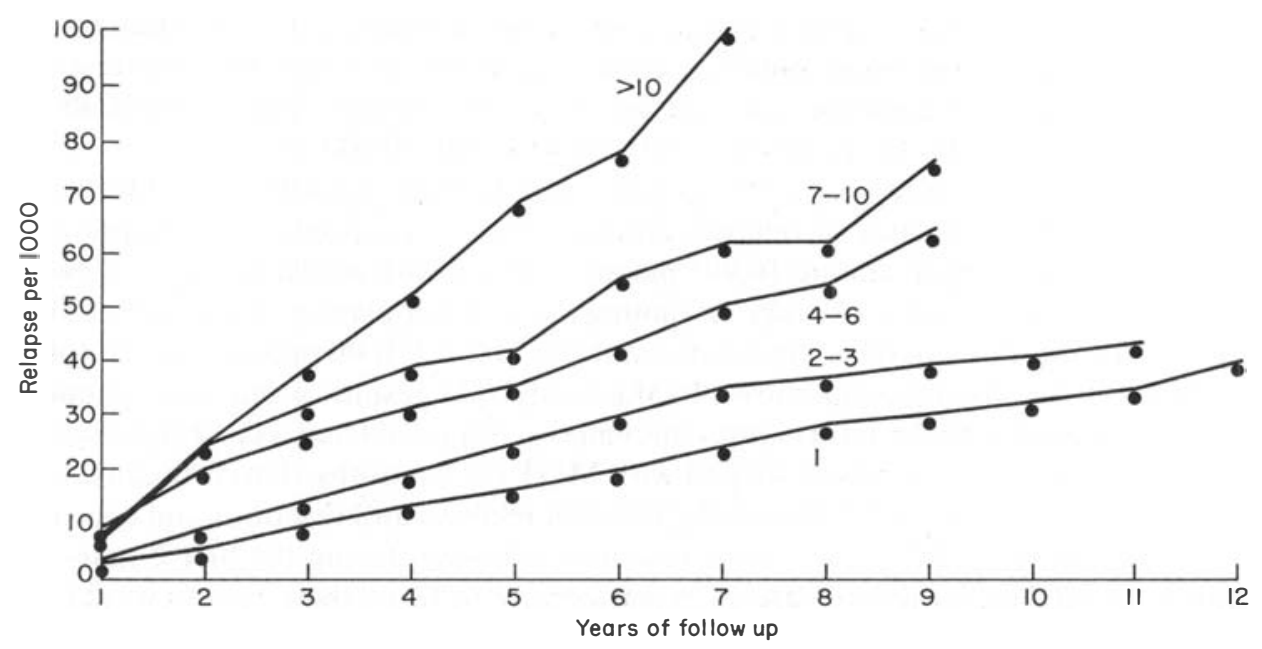

Figure 1. Cumulative risk of relapse (per 1000) according to year of follow-up by number of patches.

\section{Discussion}

The annual risk of relapse following RFT appears to remain steady for 7-9 years at about 5 per 1000. Jesudasan' studied relapse rates according to the time after RFT and reported the relapse rates to be about $13 / 1000$ for the first 2 years and about $5 / 1000$ subsequently. The design of that study varied from the present one, in that, there was a one time special verification of all RFT cases. Neelan ${ }^{2}$ had reported that relapse after RFT remained the same over the first $4 \frac{1}{2}$ years of follow-up. This study suggests that the phenomenon of relapse occurs relentlessly for fairly long periods after releasing from treatment which is incompatible with the concept of median incubation period of $3 \frac{1}{2}$ years suggested by Pattyn. ${ }^{3}$

The finding that the males had a higher rate of relapse was similar to what has been reported by Jesudasan. One possible reason for this could be differential surveillance. On the other hand this finding is consistent with the reduced risk of disease and higher rate of remission ${ }^{2}$ that women seem to enjoy.

The striking association between the risk for relapse and the number of patches is consistent with the findings from other studies. ${ }^{1,2}$

The effect of age on the relapse rate could be a function of the severity of the disease, since with increasing age at detection the severity also increases incipiently. Similarly the duration of treatment could be a surrogate for severity of disease. Patients whose lesions took a longer time to resolve could have received longer duration of treatment. Thus it appears possible that the duration of time taken for the resolution of lesions may be related to the risk of relapse.

The overall absolute risk for relapse per year is only about 5/1000 in this group and could be considered a conservative estimate. Maintaining all patients under active surveillance may not be cost effective. On the other hand it may be worthwhile following up individuals with multiple lesions since the risk of relapse is quite high even if they have had prolonged treatment. 
Though, these results are based on the analysis of secondary data, they should reflect the load of relapses that occur during routine field work. It is difficult to estimate the proportion of dapsone-resistant cases among them. An average control unit of 400,000 population in a hyperendemic district may have about 10,000 known cases of nonlepromatous leprosy, released after treatment with dapsone monotherapy. One should expect to get about 50 cases of relapses annually from this population. Chopra et al. ${ }^{4}$ reported 21 relapses from among 10,995 patients treated with paucibacillary regime and followed up to a maximum of 4 years. Assuming that this population yielded about 21,000 person years of follow-up the relapse rate would be about $1 / 1000$ person years of followup, which is lower than the one shown by this study. The results of our study cannot be directly compared with the information on relapses, obtained from a careful prospective follow-up of paucibacillary cases treated with MDT for 6 months. This is because of the difficulties one may face in distinguishing between relapses and reactions and because of the well-known fact that risk for these reactions is higher during the first 2 years after initiation of treatment. In the case of monotherapy most of these events would have occurred during therapy and not after release from treatment. Similarly, frequent and careful follow-up may yield a larger number of events related to changes in the nature and extent of the patches which, probably would be missed, during routine surveillance.

Even though there is a problem of comparing absolute rates of relapses between a historical cohort study and a concurrent cohort study, the pattern of relapses and the factors that modify the risk of relapse are likely to be similar for both those treated with monotherapy and MDT. Further, as shown in this study, the risk of relapse may remain constant over a long period of time after releasing from treatment.

\section{Acknowledgments}

We are grateful to the Damien Foundation for providing the financial help, the Epidemiology Resource Centre at Christian Medical College, Vellore for providing the assistance in data analysis and the Government of Tamil Nadu for the permission to use data.

\section{Ref erences}

1 Jesudasan K, Christian M, Bradley D. Relapse rates among non-lepromatous patients released from control. Int J Lepr, other Mycobact Dis, 1984; 52(3): 304-10.

2 Neelan PN. Inactivations and relapse in bacterio-negative cases of leprosy under sulphone therapy: a $4 \frac{1}{2}$ years follow-up. Lepr. India, 1976; 48(4 Suppl.): 661-7.

${ }^{3}$ Pattyn SR. Incubation period of relapse after treatment of paucibacillary leprosy. Lepr Rev, 1984; 55(2): 155-20.

${ }^{4}$ Chopra NK, Agarwal JS, Pandya PG. A study of relapse in paucibacillary leprosy in a multidrug therapy project, Baroda District, India. Lepr Rev (1990); 61: 157-62. 


\section{Appendix I}

Effect of age, number of patches and duration of treatment on risk for relapse (Cox's proportional hazards model)_males

\begin{tabular}{|c|c|c|c|}
\hline Term & Hazard ratio & $95 \%$ Con & e bounds \\
\hline \multicolumn{4}{|l|}{ Age } \\
\hline $0-10$ & $1 \cdot 000 *$ & - & - \\
\hline $11-20$ & $1 \cdot 142$ & 1.059 & $1 \cdot 231$ \\
\hline $21-30$ & $1 \cdot 251$ & $1 \cdot 154$ & $1 \cdot 357$ \\
\hline $31-40$ & $1 \cdot 306$ & $1 \cdot 209$ & $1 \cdot 410$ \\
\hline$>40$ & 1,440 & $1 \cdot 340$ & 1.547 \\
\hline \multicolumn{4}{|l|}{ NOP } \\
\hline 1 & $1 \cdot 000^{*}$ & - & - \\
\hline $2-3$ & $1 \cdot 007$ & 0.9511 & 1.067 \\
\hline $4-6$ & $1 \cdot 162$ & 1.071 & $1 \cdot 261$ \\
\hline $7-10$ & $1 \cdot 270$ & $1 \cdot 142$ & $1 \cdot 411$ \\
\hline$>10$ & $1 \cdot 710$ & $1 \cdot 566$ & $1 \cdot 868$ \\
\hline \multicolumn{4}{|l|}{ Treatment } \\
\hline$<3$ years & $1 \cdot 000^{*}$ & - & - \\
\hline $4-5$ years & $1 \cdot 357$ & $1 \cdot 281$ & $1 \cdot 438$ \\
\hline$>6$ years & $1 \cdot 391$ & $1 \cdot 299$ & $1 \cdot 490$ \\
\hline
\end{tabular}

* Ref erence category; NOP: Number of patches.

\section{Appendix II}

Effect of age, number of patches and duration of treatment on risk for relapse (Cox's proportional hazards model) females

\begin{tabular}{|c|c|c|c|}
\hline Term & Hazard ratio & $95 \%$ Con & bounds \\
\hline \multicolumn{4}{|l|}{ Age } \\
\hline $0-10$ years & $1 \cdot 000^{*}$ & - & - \\
\hline $11-20$ years & $1 \cdot 181$ & $1 \cdot 079$ & $1 \cdot 294$ \\
\hline $21-30$ years & $1 \cdot 253$ & $1 \cdot 152$ & $1 \cdot 363$ \\
\hline $31-40$ years & $1 \cdot 232$ & $1 \cdot 142$ & $1 \cdot 328$ \\
\hline$>40$ years & $1 \cdot 363$ & $1 \cdot 267$ & 1.467 \\
\hline \multicolumn{4}{|l|}{ NOP } \\
\hline 1 & $1 \cdot 000^{*}$ & - & - \\
\hline $2-3$ & 1.020 & 0.9646 & 1.079 \\
\hline $4-6$ & $1 \cdot 139$ & 1.050 & $1 \cdot 236$ \\
\hline $7-10$ & $1 \cdot 200$ & 1.063 & $1 \cdot 355$ \\
\hline$>10$ & $1 \cdot 568$ & 1.415 & 1.737 \\
\hline \multicolumn{4}{|l|}{ Treatment } \\
\hline$<3$ years & $1 \cdot 000^{*}$ & - & - \\
\hline $4-5$ years & $1 \cdot 508$ & $1 \cdot 422$ & $1 \cdot 600$ \\
\hline$>6$ years & $1 \cdot 580$ & 1.468 & $1 \cdot 700$ \\
\hline
\end{tabular}

* Reference category; NOP: Number of patches. 


\title{
Risque de recidives chez les patients non-lepromateux chez qui le traitement a ete arrete apres une monotherapie par la dapsone
}

\author{
T D Pandian, Jayaprakash Muliyil et Claire Vellut
}

Résume Les données relatives à 14.625 patients non-lépromateux chez qui le traitement a été arrêté après une monothérapie à la dapsone et suivis pendant un maximum de 15 ans dans le cadre du projet ELEP à Dharmapuri en Inde, furent examinées pour déterminer le profil des récidives. Le nombre total des récidives était de 5/1·000 personnes par an. Le nombre de récidives chez les hommes était plus élevé que chez les femmes. Le risque de récidive augmentait avec l'âge, le nombre de lésions et la durée du traitement. Le risque de récidive restait constant plusieurs années après la fin du traitement. Quoique le risque absolu de récidive après $M D T$ puisse être différent, le profil des récidives et les facteurs déterminants peuvent être semblables à ceux mentionnés dans cette étude.

\section{Riesgo de recaída en los pacientes no lepromatosos liberados del tratamiento de monoterapia con dapsona}

\author{
T D Pandian, Jayaprakash Muliyil y Claire Vellut
}

Resumen La información de 14.625 pacientes no lepromatosos liberados del tratamiento de monoterapia con dapsona y seguidos hasta un máximo de 15 años fue analizada en el proyecto ELEP, en Dharmapuri, India, para estudiar el modo de desarrollo de las recaídas. La tasa de recaída en conjunto fue de 5/1000 años personas. Los hombres tuvieron una tasa de recaída más alta que las mujeres. El riesgo a la recaída aumentó con la edad, número de lesiones y duración del tratamiento. El riesgo de recaida permaneció constante durante varios años después de la liberación del tratamiento. Aún cuando el riesgo de recaída absoluto después de $M D T$ puede ser diferente, el modo de recaidas y los factores que lo af ectan pueden ser similares a los que se han mostrado en este estudio. 